\title{
Natural Dyes from Fruit Waste as a Sensitizer for Dye Sensitized Solar Cell (DSSC)
}

\author{
I N. Setiawan ${ }^{1)^{*}}$, I. A. D. Giriantari1), W. G. Ariastina ${ }^{1)}$, I. B. Swamardika ${ }^{1)}$, \\ A. S. Duniaji ${ }^{2)}$ and N Satya Kumara ${ }^{1)}$ \\ ${ }^{1}$ Departement of Electrical and Computer Engineering \\ ${ }^{2}$ Department of Food Science and Technology \\ University of Udayana, \\ Bali, Indonesia \\ *setiawan@unud.ac.id
}

\begin{abstract}
Dye-sensitized solar cell (DSSC) is one of the potential candidates for the next generation solar cells. One of the most attractive features of the DSSC is the low production costs. The utilization of natural dyes is a new area for investigation due to their unique capability to absorb photons from natural sunlight or artificial light and convert it into electric current. The purpose of this study is to determine the potential of natural dye from red dragon fruit waste as a dye sensitizer. Red dragon fruit peel is initially extracted using methanol and the solution absorption spectra then is characterized using UV-Vis spectrophotometer. The absorption spectra is measured within a wavelength range of $400-800 \mathrm{~nm}$. The characterization results show that the maximum absorption spectrum is at a wavelength of $446 \mathrm{~nm}$. The natural dye solution then is used to immerse Fluorine Tin Oxide (FTO) coated with titanium dioxide $\left(\mathrm{TiO}_{2}\right)$. The glass FTO is immersed in the dye solution for 24 hours. DSSC then is prepared by sandwiching the working electrode and counter electrode. An electrolyte solution is used to fill the interface between the two electrodes. The current and voltage (I-V) characteristics of DSSC is finally measured using amperemeter and voltmeter. The results indicated that the natural dye from the peel of red dragon fruit has potential as a dye sensitizer. Further research is still required to improve the performance of the DSSC
\end{abstract}

Index Terms-Dye Sensitized Solar Cell, natural dyes, Anthocyanin, Titanium dioxide, Fluorine Tin Oxide.

\section{INTRODUCTION}

Environmental and energy crises are lately turning as global issues. An increase of $\mathrm{CO}_{2}$ emission which triggers global warming mostly reflects an increase in fossil energy consumption. The climate change has been ongoing and the impact is gradually more noticeable. Renewable energy development as an alternative for fossil fuel is one of the most proper options to overcome the environmental and energy crises. Fossil fuel, in addition to act as a contributor of $\mathrm{CO}_{2}$ gas, its availability is running off, since it needs an extremely long time to form such fuel. An alternative energy whose utilization can be improved is solar energy. Solar is the biggest source of energy in the earth. Solar cell or commonly known as photo-voltaic (PV) is a device which is able to convert the sunlight directly into electricity.

Various technology of solar cell making keep being observed and developed in order to be able to reduce the production cost of solar cell so that it can compete with fossil source of energy. The first generation which has been successfully developed by the researchers is a technology which uses single crystal silicone material. This technology is able to generate solar cell in astronomically high efficiency, but its production cost is quite costly [1]. The second generation solar cell is known as thin film solar cell which is made using a technology of thin layer since the thickness of its constituent materials are less than $1 \mu \mathrm{m}$, i.e, 100-1000 times thinner than the first generation's. This cell consists of thin films which is based on silicone amorphous. Its production cost is more reasonable, however, its efficiency is lower compared to the first generation's. Amorphous silicon (A-Si), cadmium telluride (CdTe), and copper indium gallium selenite (CIGS), all have been considered as the ultimate candidates for thin films. There 
are three types of thin film solar cell, namely mono or single junction, double or twin junction, and multiple junctions. The main difference between these structures is the number of $\mathrm{p}$ i-n junction layers [2]. Nano-technology development, domination of such solar cell made of silicone is gradually altered by the presence of Dye-Sensitized solar cell (DSSC) which is the cell of third generation. DSSC is one of potential candidates of the future solar cell, since it does not need material in high purity so that the production process cost is relatively low. DSSC is different from solar cell on silicone basis. In DSSC, there is separation between light absorption function and the transport of charge carrier. Light absorption is conducted by the molecules of dye and charge separation is conducted by nanocrystal inorganic semiconductor which has wide band gap such as $\mathrm{TiO}_{2}$. Generally, components of Dye-sensitized Solar Cell (DSSC) consists of three main components, namely the working electrode, counter electrode and electrolyte solution in Fig. 1 [3].

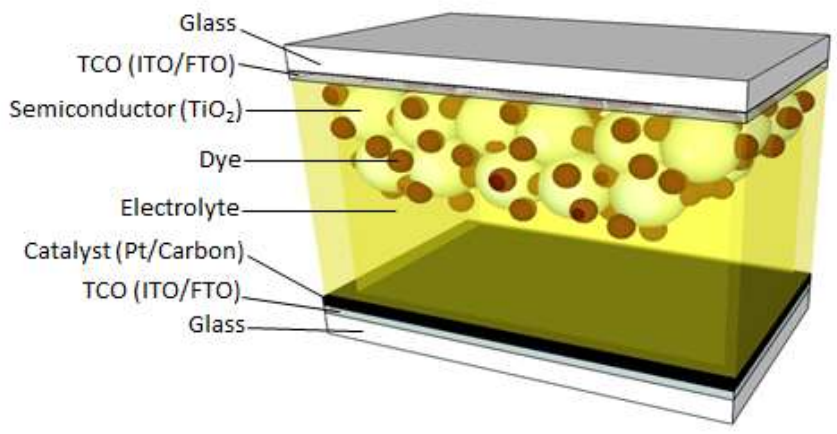

Fig. 1. Structure of Dye-sensitized Solar Cell

The working electrode consists of transparent conductive glass such as Indium Tin Oxide (ITO) or Flourine Tin Oxide (FTO), nanocrystal semiconductor layer of $\mathrm{TiO}_{2}$ and dye active layer. The counter electrode consists of transparent conductive glasses coated in carbon [4] or platinum [5]. The electrolyte used is electrolyte of iodin triodida with the redox pair of $\left(\mathrm{I}^{-} / \mathrm{I}_{3}{ }^{-}\right)$. Fabrication simplification with the availability of plentiful materials and plus the reasonable efficiency has made DSSC is considered as promising to be an inexpensive solar cell.

Dye as sensitizers play a key role in the absorption of photons from sunlight and transform them into electricity. The use of synthetic dyes as sensitizers may provide a better efficiency of DSSC and a higher durability, however it shows several shortcomings such as higher cost, tendency to degrade and potential of the usage of toxic materials [6]. As an alternative, natural dyes are used as sensitizers. Natural dyes are extremely attractive for the application of DSSC since it is quite inexpensive, continuous and widely available in Indonesia [7]. Research on DSSC using natural dyes which had been conducted was utilizing the leaves, fruits, roots and mushrooms [8-11]. In this research, a study on the establishment of the prototype of Dye Sensitized Solar Cells (DSSC) by utilizing waste from red dragon fruit was conducted. As many as 30-35\% part of dragon fruit is its peel, however, it is commonly thrown away as a waste which may pollute the environment. Peel from red dragon fruit contains a quite high level of anthocyanin natural dyes substances [12-14]. Anthocyanin is a dye taking role to provide red color. Utilization of waste as an extract of natural dye will be less costly and may improve the added value compared to the utilization of its fruit flesh. In addition, the utilization of peel may minimize the waste production which is getting higher along with the increase of the number of population's consumption. Government of Indonesia by the next 2016 plans to require the companies producing waste to utilize their generated waste. This policy is conducted by the government of Indonesia to optimize waste of energy which is considered as a step of contribution in Indonesia in reducing global green house gas emission as many as $29 \%$ by 2030 [15].

This research as an initial study for the further research expects that in the future it may generates several opportunities for domestic industrial reinforcement in the form of creation for superior products as the innovation of the nation itself.

\section{MethodS AND PROCEDURES}

The materials used in this research are thin films of $\mathrm{TiO}_{2}$ on TCO22-7 FTO glass with material resistivity of $7 \mathrm{ohm} /$ sq (Solaronix SA). An active layer of Ti-Nanoxide T/SP is covered by reflective layer from Ti-Nanoxide R/SP using screen printing method. Conductive glass of Fluorine Tin Oxide (FTO) size of $20 \times 20 \mathrm{~mm}$ and thickness of $2 \mathrm{~mm}$. Active layer of $\mathrm{TiO}_{2}$ on FTO glass with $6 \times 6 \mathrm{~mm}$ in size is provided in Fig. 2. In this research, dyes from the peel of red dragon fruit with methanol solvent is used. The peel of red dragon fruit is separated from its flesh. The peel of red dragon fruit is cut in piece and the it is dried. The dried peel of dragon fruit is blended until it turns into powder. Moreover, the powder of dragon fruit peel is extracted by means of maceration, meaning that the dragon fruit peel is soaked for 24 hours in $96 \%$ methanol until the powder of dragon fruit peel is completely soaked. After 24 hours, the extract is filtered and the product of extraction is accommodated. The working electrode in the form of FTO conductive glass which has been layered with $\mathrm{TiO}_{2}$ is immersed in dye for 24 hours. UV-Vis absorption spectrum of dye sample is characterized using UV-Vis Spectrophotometer (UV-1800 Shimadzu). The counter electrode is in the form of FTO conductive glass which has been layered with $6 \mathrm{~B}$ pencil [16]. The working electrode is stacked with the counter electrode and in between of those two, some drops of electrolyte solution (Iodolyte HI-30) is given, then the both side is clamped together using binder clips. The current and voltage of the formed DSSC is characterized using voltmeter $(\mathrm{V})$ and ammeter $(\mathrm{A})$. 


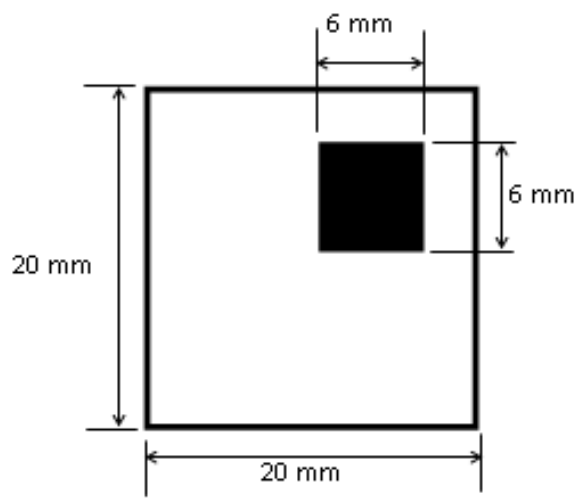

Fig. 2. The active layer of $\mathrm{TiO}_{2}$ on glass FTO

\section{RESULTS}

Dye solution made of extract of red dragon fruit peel using methanol solvent which is able to absorb and transmit the spectrum of visible light. These dye substances functions as dye sensitizers. Before it is used as sensitizers, the dye solution is characterized in advance using UV-Vis Spectrophotometer to identify the absorption power of extract of red dragon fruit peel upon visible wavelength. The absorption spectrum is calculated in the range of wavelength of 400-800 $\mathrm{nm}$. The characterization result of absorption spectrum is such as what seen in Fig. 3. Extract of red dragon fruit peel is proved to have an absorption power on the wave of visible length, meaning that it is seen on the peak of absorption in the wavelength of $446 \mathrm{~nm}$.

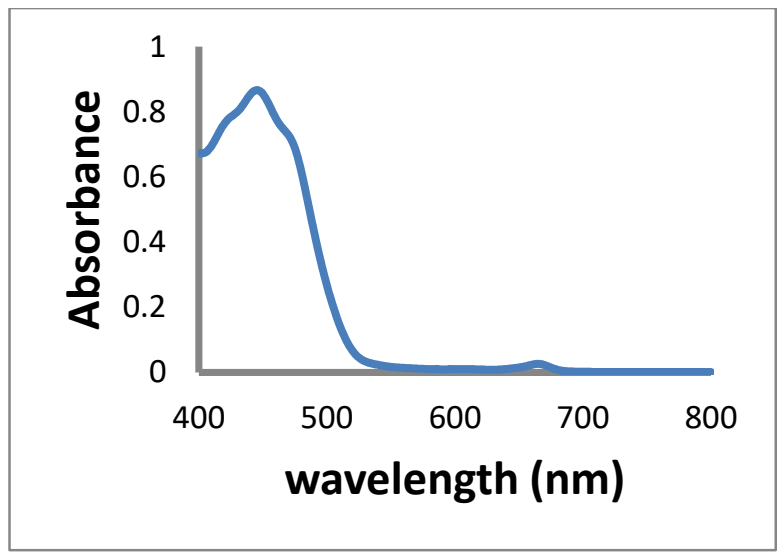

Fig. 3. Dye absorption spectrum of the red dragon fruit peel.

The testing of DSSC energy conversion ability is conducted using 220 Volt, 500 Watt halogen source of light such as what can be seen in Fig. 4. DSSC is able to convert the halogen light into electricity which is shown by the voltage value on multimeter of $247.1 \mathrm{mV}$ or 0.2471 and the electric current of $4.5 \mu \mathrm{A}$. According to the result of the test, it can be seen that the generated voltage is considered as quite good and stable, however, the generated current is not quite optimal. It is because the resistance of DSSC which is still quite large so that it may cause the electrons injected from the dye will overcome an obstruction so that the number of the electrons flowing turns smaller. The current generated also relates to the amount of photons engaged in the process of conversion and it depends on the intensity of radiation and the performance of the dye utilized. Stability of generated current value from DSSC made is still low, so that the result obtained is not optimal enough to obtain I-V curve. The initial research of the making of DSSC using red dragon fruit peel material has been able to be conducted, but the result is not optimal enough, so that an advanced research is still need to be conducted to improve the performance of DSSC.

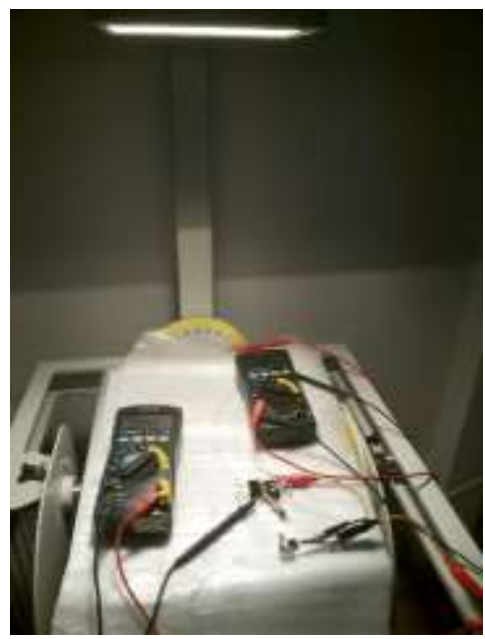

Fig. 4. Testing DSSC with halogen light source $220 \mathrm{~V}, 500 \mathrm{~W}$.

\section{CONCLUSION}

In this research, the Dye Sensitized Solar Cell using natural dyes from red dragon fruit waste as dye sensitizers has been conducted. The red dragon fruit peel is extracted using methanol. The absorption spectrum is calculated in the range of wavelength of 400-800 $\mathrm{nm}$. Characterization result shows that the maximum absorption of spectrum in the wavelength of $446 \mathrm{~nm}$. The natural dye taken from red dragon fruit peel has a potential as dye sensitizers. The test results DSSC using halogen light source generates an open circuit voltage of $247.1 \mathrm{mV}$ and short circuit current of 4.5 $\mu \mathrm{A}$. A further research remains to be required in order to improve the performance of DSSC.

\section{ACKNOWLEDGMENT}

The work was financially supported by the University of Udayana, grants No : 641-30/UN14.2/PNL.01.03.00/ 2016, which are gratefully acknowledged. The authors would like to thank the entire staff of the Laboratory of Energy Conversion, Department of Electrical and Computer Engineering and Laboratory of Integrated, Faculty of Mathematics and Natural Sciences. 


\section{REFERENCES}

[1] Richhariyaa G., Anil Kumara, Perapong Tekasakul, Bhupendra Gupta, 2017. Natural dyes for dye sensitized solar cell: A review Renewable and Sustainable Energy Reviews 69 (2017) 705-718

[2] Al-Alwani, M.A.M., AbuBakarMohamad, Norasikin A. Ludin, Abd. Amir H. Kadhum, Kamaruzzaman Sopian, 2016. Dye-sensitised solar cells: Development, structure, operation principles, electron kinetics, characterisation, synthesis materials and natural photosensitisers. Renewable and Sustainable Energy Reviews 65 183-213

[3] Grätzel, M, 2003. "Dye-sensitized solar cells. " Journal of Photochemistry and Photobiology C:Photochemistry Reviews, vol. 4(2), pp.145-153

[4] Kyaw,K., A.K, H. Tantang,T.Wu, L. Ke, J.Wei, H. V. Demir,Q. Zhang and X.W. Sun, 2012. Dye-sensitized solar cell with a pair of carbonbased electrodes, J. Phys. D, vol. 45, pp. 165103.

[5] Adachi, T and H. Hoshi, 2013. Preparation and characterization of $\mathrm{Pt} /$ carbon counter electrodes for dye-sensitized solar cellsm, Materials Letters, vol.91, pp. 15-18

[6] Shalini,S., R. Balasundara prabhu, S. Prasanna, Tapas K. Mallick,S. Senthilarasu, 2015. Review on natural dye sensitized solar cells: operation, materials and methods, Renewable and Sustainable Energy Reviews, Vol. 51 (2015), doi:10.1016/j.rser.2015.07.052

[7] Setiawan, I.N., Ida Ayu Dwi Giriantari, W.Gede Ariastina, I Nyoman Satya Kumara, 2015, Sel Surya Berbasis Pewarna Alami dan Potensi Pengembangannya di Indonesia sebagai Sumber Energi Alternatif yang Ramah Lingkungan, Prosiding Seminar Nasional Ketenagalistrikan dan Aplikasinya (SENKA). Bandung 19-20 Agustus 2015

[8] Abdel-Latif, Monzir S., Mahmoud B. Abuiriban, Taher M. El-Agez, and Sofyan A. Taya, 2015. Dye-Sensitized Solar Cells Using Dyes Extracted From Flowers, Leaves, Parks, and Roots of Three Trees, INTERNATIONAL JOURNAL of RENEWABLE ENERGY RESEARCH, Vol.5, No.1

[9] Zalas,M., BBahej Gierczyk, Hubert Bogacki, and Grzegorz Schroeder, 2015. The Cortinarius Fungi Dyes as Sensitizers in Dye-Sensitized Solar Cells, Hindawi Publishing Corporation International Journal of Photoenergy Volume 2015, Article ID 653740, 6 pages http://dx.doi.org/10.1155/2015/653740

[10] Maabong, K, C. M. Muiva, P. Monowe, T. S. Sathiaraj, M. Hopkins, L. Nguyen, K. Malungwa and M. Thobega, 2015. Natural Pigments as Photosensitizers for Dye-Sensitized Solar Cells with $\mathrm{TiO}_{2}$ Thin Films, INTERNATIONAL JOURNAL of RENEWABLE ENERGY RESEARCH, Vol.5, No.1.

[11] Torchani,A., S. Saadaoui, R. Gharbi, M. Fathallah. 2015. Sensitized solar cells based on natural dyes. Current Applied Physics 15 307-312

[12] Handayani, PA dan Rahmawati,A, 2012. Pemanfaatan Kulit Buah Naga (Dragon Fruit) Sebagai Pewarna Alami Makanan Pengganti Pewarna Sistetis, Jurnal Bahan Alam Terbarukan, Vol. 1 No. 2

[13] Simanjuntak, L, Chairina Sinaga, Fatimah, 2014. Ekstraksi Pigmen Antosianin dari Kulit Buah Naga Merah (Hylocereus polyrhizus), Jurnal Teknik Kimia USU, Vol. 3, No. 2.

[14] Putri, N.K.M, I Wayan Gede Gunawan, dan I Wayan Suarsa, 2015 , Aktivitas Antioksidan dalam Ekstrak Etanol Kulit Buah Naga Super Merah (Hylocereus costaricensis) dan Analisis Kadar Totalnya, JURNAL KIMIA 9 (2), JULI 2015: 243-251

[15] Kementerian Energi dan Sumber Daya Mineral,2016. Tahun 2018, Pemerintah Akan Wajibkan Perusahaan Manfaatkan Limbah Yang Dihasilkan Tersedia : http://www.esdm.go.id/berita/ energi-baru-danterbarukan/323-energi-baru-dan-erbarukan/8102-tahun-2018pemerintah-akan-wajibkan-perusahaan-manfaatkan-limbah-yangdihasilkan.html diakses tanggal 17 Pebruari 2016

[16] Martineau, David, 2012 , Dye Solar Cells for Real, The Assembly Guide for Making Your Own Solar Cells, Solaronix SA Rue de l'Ouriette $129 \mathrm{CH}-1170$ Aubonne Switzerland. 